\title{
EFFECTS OF THE NEUROGENIC CELLS SUPERNATANT ON THE TUMOR-INDUCING ABILITY OF GLIOMA 101.8 IN RATS
}

\section{ABSTRACT}

The use of neurogenic stem cells (NSCS) and neurogenic progenitor cells (NPCS) is one of the areas of brain and spinal cord lesions cell therapy. Intensive research of NSCs biology has revealed their tumor-tropic properties. Great migration potential and integration of NSCs in places of pathology in the central nervous system allows to consider their application as a means of targeted therapy of tumors. Antitumor properties of NSCs substantiate the development of treatment strategies for malignant gliomas using NSCs.

The aim was to study the effect of rat neurogenic cells supernatant (NCS) on the tumor-inducing ability of glioma 101.8 cells at the intracerebral implantation in rats.

Brain glioma 101.8 was modeling by intracerebral injection of 101.8-glioma cells suspension. NCS was received from whole rat brain tissue on 14th (E14) day of gestation.

Modification of 101.8-glioma cells suspension by means of incubation with NCS (0.02 and $0.1 \mathrm{mg} / \mathrm{ml})$ reduced the tumor-inducing ability of tumor cells, postponing the time of tumor clinical manifestations debut and increasing the lifetime of experimental animals.

Under conditions of glioma induction with tumor cells, previously modified by NCS, cytotoxic activity of immune cells of tumor-bearing animals in MTT-test with allogeneic 101.8-glioma cells was increased.

KEY WORDS: glioma 101.8; neurogenic progenitor cells supernatant; cytotoxic activity of lymphocytes

Malignant gliomas of the brain are characterized by invasive growth and resistance to the treatment and have a poor prognosis for patients' lives. Highly malignant gliomas can not be treated by surgical resection; and toxicity of chemotherapy and radiotherapy limits the doses that can be used.

The use of neurogenic stem cells (NSCs) and neurogenic progenitor cells (NPCs) is one of the areas of cell therapy of brain and spinal cord lesions. Intensive research of NSCs biology has revealed its tumor tropic properties. A great potential of migration and incorporation of NSCs in the place of the pathology in the CNS can consider their use as a means of targeted therapy of tumors [1-7]. Antitumor properties of NSCs substantiate the development of strategies of malignant gliomas treatment with NSCs [8-10].

The issue of possible mechanisms for implementing of NSCs/NPCs anti-tumor properties is understudied; and, since there are prospects of their use for the treatment of brain lesions and malignant brain tumors, a research in this area is important.

The aim of the paper was to study the effect of rat neurogenic cells supernatant (NCS) on the tumor-inducing ability of 101.8-glioma cells at the intracerebral implantation in rats.

\section{MATERIALS AND METHODS}

The studies were conducted on white rats $(\mathrm{n}=60$ males, weight $120 \pm 10 \mathrm{~g}$ ) from the vivarium of A. P. Romodanov State Institute of Neurosurgery NAMS of Ukraine. All animal experiments were performed in accordance with Law of Ukraine "On protection of animals from cruelty", the "European Convention for the Protection of Vertebrate Animals used for experimental and other scientific purposes", all norms of bioethics and biosafety and were approved by Bioethics Committee. The animals were kept under standard vivarium conditions; anesthesia and euthanasia were performed under ether anesthesia.

The model of glioma 101.8 was prepared by intracerebral administration $0.02 \mathrm{ml}\left(3,5 \cdot 10^{5}\right.$ viable cells) of native or modified strain of 101.8-glioma cells suspension (All-Russian Collection of Cell Cultures, Institute of Human Morphology of Russian Academy of Sciences, Moscow, Russia) in the left hemisphere of the rat brain to the depth of $1.5-2.0 \mathrm{~mm}$. Strain 101.8 is an anaplastic glioma in which astrocytes glia oligodendroglia and ependyma underwent simultaneous malignancy, and its histobiological properties are close to the human malignant gliomas [11]. 
Animals were simultaneously introduced in the experiment and divided into the following groups:

1. induction of glioma was carried out with native 101.8-glioma cells $(n=15)$;

2. glioma induction was carried out with tumor cells modified with RPNS at a concentration of $0.02 \mathrm{mg} / \mathrm{ml}(n=15)$;

3. induction of glioma was carried out with tumor cells modified with NCS at a concentration of $0.1 \mathrm{mg} / \mathrm{ml}(\mathrm{n}=15)$;

4. intact rats (control, $\mathrm{n}=15$ ).

We analyzed the timing of clinical manifestations of tumor, the life span of experimental animals. At the peak of clinical manifestations rats' spleens were removed for immunological tests (determination of cytotoxic activity of immunocompetent cells).

Obtaining of tumor cell suspensions for intracerebral implantation. At the peak of clinical manifestations of the tumor the animals were anesthetized and the tumor was removed. The tumor tissue was washed in DMEM medium (Sigma, USA), separated from vessels and shells, minced with microscissors in the DMEM medium and mechanically dissociated by multiple pipetting. The cells were pelleted by centrifugation for $5 \mathrm{~min}$ at $1500 \mathrm{rpm}$, washed in the DMEM medium, fresh DMEM medium was added to the cells pellet. Than the cells were adjusted to the desired concentration and resuspended (native suspension). The viability of cells in suspension was determined by the permeability of the plasma membrane to $0.2 \%$ trypan blue dye (Merck Germany) [18]. For modification NCS $(0.02,0.1 \mathrm{mg} / \mathrm{ml})$ were added to the native suspensions of freshly isolated cells $\left(2.0 \cdot 10^{6}\right)$ and, at the volume of $2 \mathrm{ml}$, incubated in glass centrifuge tubes with periodic shaking for $24 \mathrm{~h}$ in a $\mathrm{CO}_{2}$ incubator at $37.0 \pm 0.5^{\circ} \mathrm{C}$, constant humidity of $95 \%$ and $5 \% \mathrm{CO}_{2}$. After the incubation, the cells were washed in DMEM medium, fresh DMEM medium was added to the cell pellet, adjusted to the desired concentration and resuspended.

Along with this, freshly isolated tumor cells in an amount of $1.10^{6}$ were deposited on adhesive cover glasses coated with polyethyleneimine (Sigma, USA), which were placed in petri dishes and cultured in 199 and DMEM mediums (1: 1) supplemented with $10 \%$ fetal calf serum, $4 \mathrm{~g} / \mathrm{l}$ glucose and $0.2 \mathrm{U} / \mathrm{ml}$ insulin (culture medium volume was $2 \mathrm{ml}$ ). The research cultures were added with NCS $(0.02,0.1 \mathrm{mg} / \mathrm{ml})$ and incubated for $24 \mathrm{~h}$. The cell cultures were kept in a $\mathrm{CO}_{2}$-incubator $\left(37^{\circ} \mathrm{C}, 95 \%\right.$ humidity and $5 \% \mathrm{CO}_{2}$ ) and observed in vivo with inverted microscope Biolam P-3 (LOMO, Russia) and Eclips TS 100 (Nikon, Japan) with photo registration.

The supernatant of neurogenic cells (SNC) was received at cultivation of rats' brain neurogenic cells removed on the $14^{\text {th }}$ (E14) day of gestation. Native rat brain tissue was separated from membranes in saline, transferred to DMEM medium (Sigma, USA) and suspended by multiple pipetting. The cells were pelleted by centrifugation for $5 \mathrm{~min}$ at $1500 \mathrm{rev} / \mathrm{min}$, washed in DMEM medium, the cell pellet was added with fresh DMEM medium and resuspended. The viability of cells in suspension was determined in a standard cytotoxicity test with $0.2 \%$ trypan blue (Merck, Germany). The concentration of cells was adjusted to $6.0 \cdot 10^{6} / \mathrm{ml}$, to the resulting cell suspension we added concanavalin $\mathrm{A}(0.1 \mathrm{mg} / \mathrm{ml})$ and incubated for 2 hours in a $\mathrm{CO}_{2}$ incubator at $37.0 \pm 0.5^{\circ} \mathrm{C}$, constant humidity of $95 \%$ and $5 \% \mathrm{CO}_{2}$. After incubation, the cells were pelleted by centrifugation for $5 \mathrm{~min}$ at $1500 \mathrm{rpm}$, washed in DMEM medium, cells pellet was added with fresh DMEM medium, resuspended and incubated for $24 \mathrm{~h}$. After incubation, the cells were pelleted once more by centrifugation for 5 min at $1500 \mathrm{rpm}$, the supernatant was collected, its protein concentration was determined by the method of Lowry, standardized to a concentration of $1.0 \mathrm{mg} / \mathrm{ml}$, aliquoted and stored at $-20 \pm 0.5^{\circ} \mathrm{C}$.

Obtaining of lymphocytes. As a source of immunocompetent cells (lymphocytes) we used the spleens of experimental animals. They were examined on the $17^{\text {th }}$ day of tumor induction (at the peak of clinical manifestations). The animals were anesthetized, the spleens were removed, splenocytes suspension was prepared by mechanical homogenization in RPMI (Sigma, USA) medium and filtered through a nylon filter. Lymphocytes were obtained by centrifugation of the splenocytes suspension in ficoll-verografin gradient $(d=1.077)$ at 1500 rpm for $30 \mathrm{~min}$, washed twice with buffered saline $\mathrm{pH}=7.2-7.4$. The number and viability of obtained cells was determined by counting them with $0.2 \%$ tripan blue (Merck, Germany).

The study of lymphocytes cytotoxic activity with MTT-colorimetric method. Cytotoxic test was performed under the protocol [12]. Lymphocytes of experimental animal groups were used as effector cells $(5 \cdot 107 / \mathrm{ml}) ; 101.8-$ glioma cells $(1.107 / \mathrm{ml})$ were used as target cells. According to the previous studies with effector target ratios 20:1, 10:1, 5:1 the optimal ratio is 5:1, which we used in this study. The test was performed in triplets. Cytotoxic activity of lymphocytes was expressed by cytotoxic index $(\mathrm{Cl})$ in percentage:

$$
C I=100-\left(\frac{O D_{e+t}-O D_{e}}{O D_{t}} 100\right) \%,
$$

Where $0 D_{\text {e+t }}$ - the value of optical density in the holes effector+target; $O D_{e}$ - the value of optical density in the holes with effectors;

$O D_{t}-$ the value of optical density in the holes with targets.

Statistical analysis was performed using the Statistica 6.0 software (StatSoft Inc., 2003). For statistical survival analysis we used KaplanMeier method of multiple estimates using Wilcoxon-Gehan test. For statistical analysis of indicator cytotoxicity we used Kruskal-Wallis ANOVA test for comparison of several independent groups and U-Mann-Whitney test for paired comparison groups. A statistically significant difference was considered when $p \leq 0.05$, highly statistically - when $p \leq 0.01$.

\section{RESULTS AND DISCUSSION}

Incubation of glioma 101.8 cells with RPNS for $24 \mathrm{~h}$ resulted in a decrease in the number and viability of tumor cells in suspension (respectively by $39 \%$ and $16 \%$ at a concentration of NCS $0.02 \mathrm{mg} / \mathrm{ml}$, $52 \%$ and $17 \%$ at a concentration of $0.1 \mathrm{mg} \mathrm{NCS} / \mathrm{ml}$ ). In vivo observation of cultures in the inverted microscope showed that incubation with NCS caused dilution and degradation of glioma 101.8 cell growth zone (Figure 1), indicating the cytotoxic effect of NCS on tumor cells.

Effect of NCS on tumor inducing ability of glioma 101.8 cells was determined by analyzing the survival of experimental animals. Application of Kaplan-Meier method of multiple estimates using Wilcoxon-Hehan criteria revealed that survival rates of animals with glioma 101.8 and different modes of NCS administration had statistically high differences ( $x^{2}$ criteria, $\left.p=0.000001\right)$. Paired comparison of groups using twosample Wilcoxon-Hehan test revealed the following features.

Modification of 101.8-glioma cells using 24-hour incubation with NCS highly increased an mean lifetime (ML) and a survival median of tumor-bearing rats compared with these figures in animals, which tumor transplantation was performed with the native glioma cell suspension $(p=0.000001$; Table 1, Fig. 2). Clinical signs of disease in rats, which were administered with native intracerebral glioma cell suspension, appeared on the first days of observation (reduction in motor activity, grooming). At the same time, in groups of animals, which were intracerebrally administered with modified NCS glioma cell suspension, clinical signs of tumor were not detected until the $26^{\text {th }}$ day. Incubation of glioma cells with $0.02 \mathrm{mg} / \mathrm{ml}$ NCS before intracerebral administration into rats resulted in an extension of animals' ML on average for 13 days and the survival median for 14 days; incubation of tumor cells with $0.1 \mathrm{mg} /$ ml NCS - respectively led to an extension of animals' ML on average for 14 days and the survival median for 17 days.

All the animals of the experimental group, which tumor transplantation was performed with the native glioma cells suspension died until $23^{\text {th }}$ day, while the maximum life span of tumor-bearing animals, which were 
intracerebrally administered with suspension of NCS modified cells was 33 days (modification with $0.02 \mathrm{mg} / \mathrm{ml} \mathrm{NCS}$ ) and 38 days (modification with $0.1 \mathrm{mg} / \mathrm{ml} \mathrm{NCS}$ ) (Fig. 2). We have not found any statistically significant differences between the survival rates of animals from experimental groups which tumor transplantation was performed with cells modified by using different concentrations of NCS.

Thus, tumor inducing ability of glioma cells, modified with NCS, significantly decreased, delaying the debut of clinical manifestations of tumor and increasing the life expectancy of experimental animals.

The comparison of cytotoxic activity of animal research groups using Kruskal-Wallis ANOVA test revealed statistically significant differences between them $(p=0.0014)$. The used version of MTT-test allows to determine the total cytotoxic activity of effector immunocompetent cells as cytotoxic lymphocytes and natural killer cells, which play a key role in the antitumor immunity. Paired comparison of groups using U-MannWhitney test revealed the following differences.

In animals, in which the induction of tumor cell suspension was performed with the native 101.8-glioma cells, the index of lymphocytes cytotoxicity on the $17^{\text {th }}$ day after tumor transplantation was highly statistically higher than the rate of intact animals (U-Mann-Whitney test, $p=0.003$, Fig. 3). Despite this, anti-tumor immunity in these animals was ineffective because tumor-bearing animals died until the $23^{\text {rd }}$ day. The latter may be due to different mechanisms by which glioma is able to escape from the control of the immune system. In particular, such mechanisms may include: glioma's secretion of immune inhibitory molecules to create immunosuppressive environment [13]; partial or complete loss of antigens of major histocompatibility complex in glioma cells $[14,15]$ and components of antigens processing mechanism [16]; appearance of expression of non-classical histocompatibility complex molecules (HLA-G, HLA-E) by glioblastoma and microglia/macrophages cells that infiltrate the tumor $[17,18]$.

In animals, which were injected intracerebrally with glioma cell suspension modified with RPNS at a concentration of $0.02 \mathrm{mg} / \mathrm{ml}$, the cytotoxic activity of immunocompetent cells was increased by an average of $16 \%$ compared with the rate of tumor-bearing animals injected with native glioma cell suspension, but not up to statistically significant level (U-Mann-Whitney test, $p=0.066$, Fig. 3). At the same time, in the test with tumor cells there turned out a statistically significant increase of $\mathrm{Cl}$ immunocompetent cells of rats, which tumor was induced with glioma cell suspension, modified with RPNS at a concentration $0.1 \mathrm{mg} / \mathrm{ml}$ (compared with that of animals with glioma 101.8, U-test Mann-Whitney, $p=0.008$, Figure 2); the average cytotoxic activity of lymphocytes was increased by $21 \%$.

$>$

Figure 1. In vitro cell culture of glioma 101.8, light microscopy, x100:

A - incubation under standard condition, $24 \mathrm{~h}$

B - incubation with NCS $(0.02 \mathrm{mg} / \mathrm{ml}), 24 \mathrm{~h}$

C - incubation with NCS $(0.1 \mathrm{mg} / \mathrm{ml}), 24 \mathrm{~h}$.
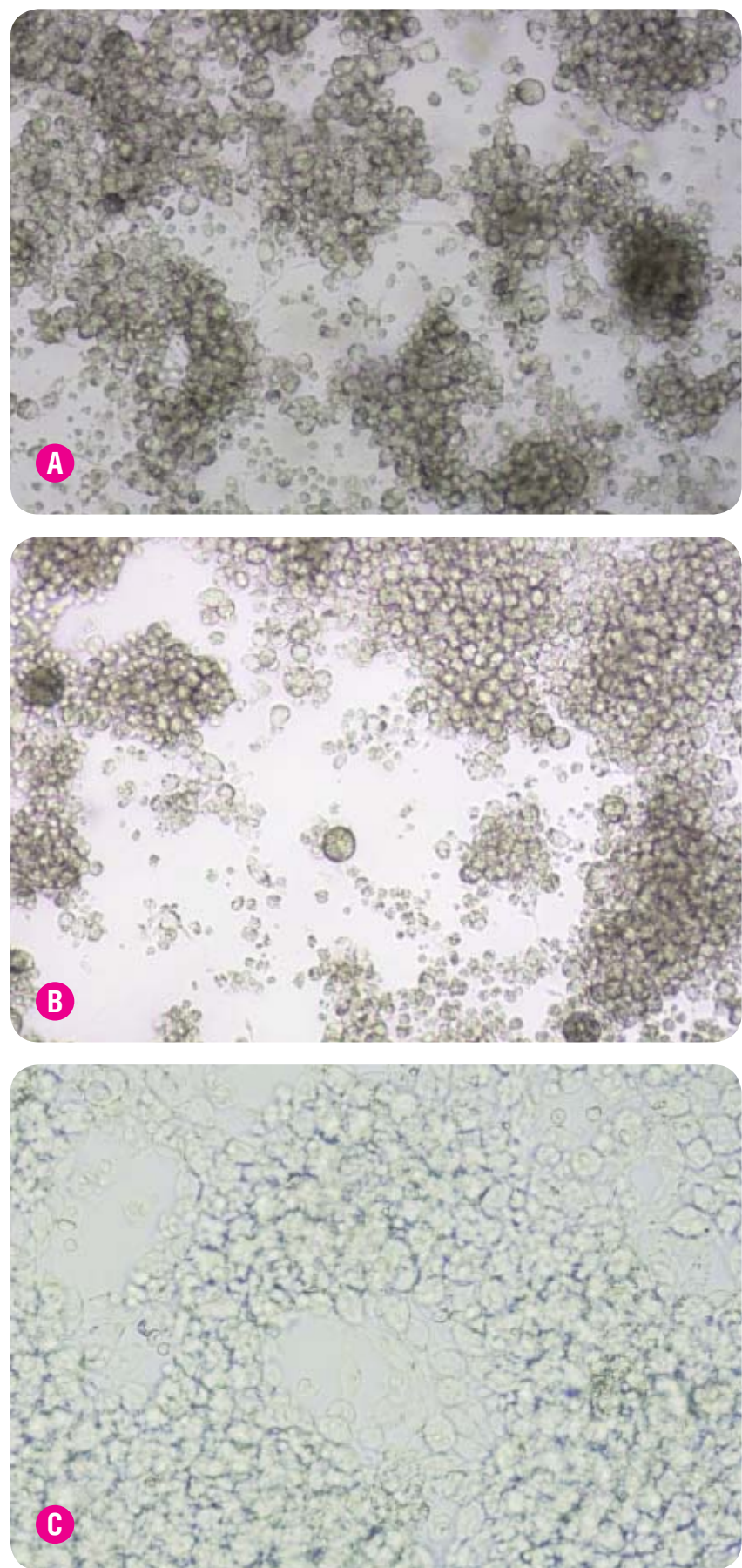

Table 1. The mean lifetime (ML) and the median of animals' survival in experimental groups with glioma 101.8.

\begin{tabular}{|c|c|c|c|c|c|c|}
\hline № & GROUP & $\begin{array}{c}\text { ML, DAYS } \\
\text { (M + M) }\end{array}$ & $\begin{array}{l}\text { 50' PERCENTILE } \\
\text { (MEDIANA), } \\
\text { DAYS }\end{array}$ & $\begin{array}{l}\text { 25' PERCENTILE } \\
\text { (LOWER } \\
\text { QUARTILE), DAYS }\end{array}$ & $\begin{array}{l}\text { 75' PERCENTILE } \\
\text { (UPPER } \\
\text { QUARTILE), DAYS }\end{array}$ & $\begin{array}{c}P \\
\text { (WILCOXON-HEHAN } \\
\text { TEST) }\end{array}$ \\
\hline 1 & $\begin{array}{l}\text { Induction of tumor with native glioma } \\
\qquad 101.8 \text { cells }(n=15)\end{array}$ & $14.6 \pm 2.8$ & 14.0 & 12.0 & 17.3 & - \\
\hline 2 & $\begin{array}{l}\text { Induction of glioma with tumor cells } \\
\text { modified with NCS at a concentration } \\
\text { of } 0.02 \mathrm{mg} / \mathrm{ml}(n=15)\end{array}$ & $27.3 \pm 3.4$ & 28.0 & 27.0 & 30.0 & $p_{1,2}=0.000001$ \\
\hline 3 & $\begin{array}{l}\text { Induction of glioma with tumor cells } \\
\text { modified with NCS at a concentration } \\
\text { of } 0.1 \mathrm{mg} / \mathrm{ml}(n=15) \text {; }\end{array}$ & $28.3 \pm 5.0$ & 31.0 & 26.0 & 33.0 & $\begin{array}{c}\mathrm{p}_{1,3}=0,000001 \\
\mathrm{p}_{2,3}=0.6809\end{array}$ \\
\hline
\end{tabular}


Thus, under conditions of glioma induction with tumor cells, previously modified with RPNS, the ability of immunocompetent cells of tumor-bearing animals to do allogeneic cytotoxic effect on glioma cells in vitro tests increased.

The reduction of tumor inducing ability of glioma cells, modified with NCS, is due to the start of signaling cascade in glioma cells under the influence NCS. They lead to an increased expression of MPC antigens class I and components of antigens processing mechanism. This contributes to the recognition of allogeneic tumor cells and, therefore, increases cytotoxic activity of immunocompetent cells. It allows to provide more effective immune response against glioma 101.8 cells and extend the life of tumor-bearing animal.
Furthermore, incubation of NCS could probably run apoptosis inducing mechanisms in glioma 101.8 cells.

The known data indicate that the rat NPC can express and produce variety of different cytokines (IL-1a, IL-1 1 , IL-6, IL-10, TGF- $\beta 1$, TGF- $\beta 2$, TNF- $\alpha$ [19-20], LIF [21]). It is likely that NCS can include TNF- $\beta$ (can provide direct cytostatic and cytotoxic effects on tumor cells) and TGF- $\beta 1$, TGF- $\beta 2$ (pro-apoptotic effect). The latter assumption can confirm earlier obtained data about increasing of cells number in the terminal stage of apoptosis (Propidium lodide positive) and $\mathrm{CD}^{+} 5^{+}$cells (carrying FAS-receptor apoptosis) in shortterm cultures of human anaplastic gliomas [22] under the influence of rat NCS.

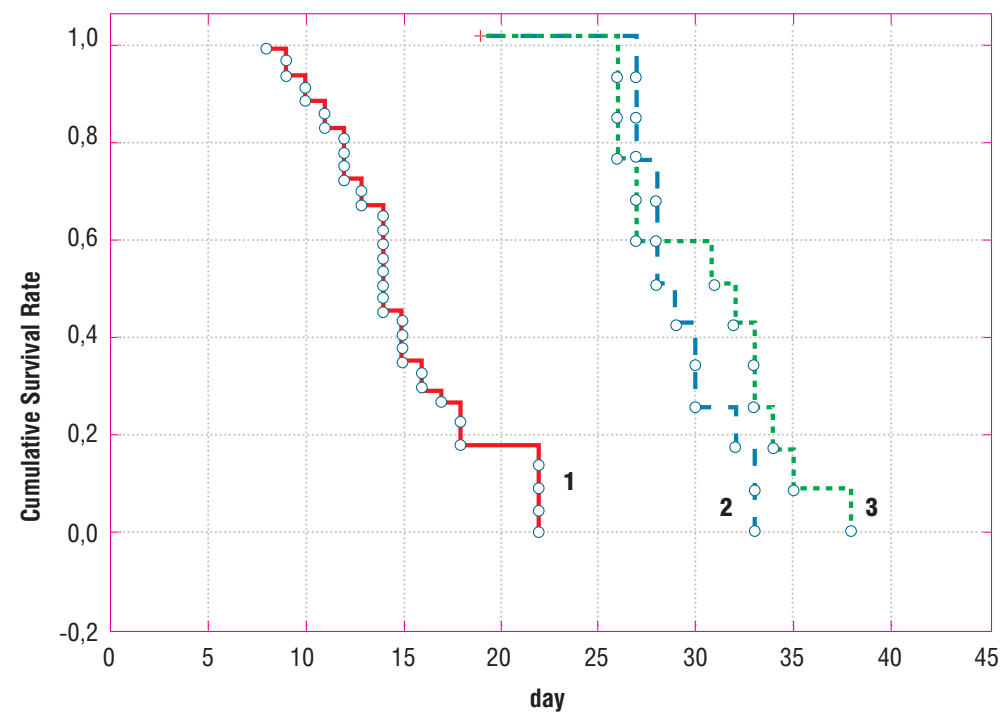

Figure 2. Animal's survival curves with glioma 101.8:

1) induction of glioma was carried out with native 101.8-glioma cells $(n=15)$;

2) induction of glioma was carried out with tumor cells modified with NCS at a concentration of $0.02 \mathrm{mg} / \mathrm{ml}(\mathrm{n}=15)$;

3) induction of glioma was carried out with tumor cells modified with NCS at a concentration $0.1 \mathrm{mg} / \mathrm{ml}(\mathrm{n}=15)$;

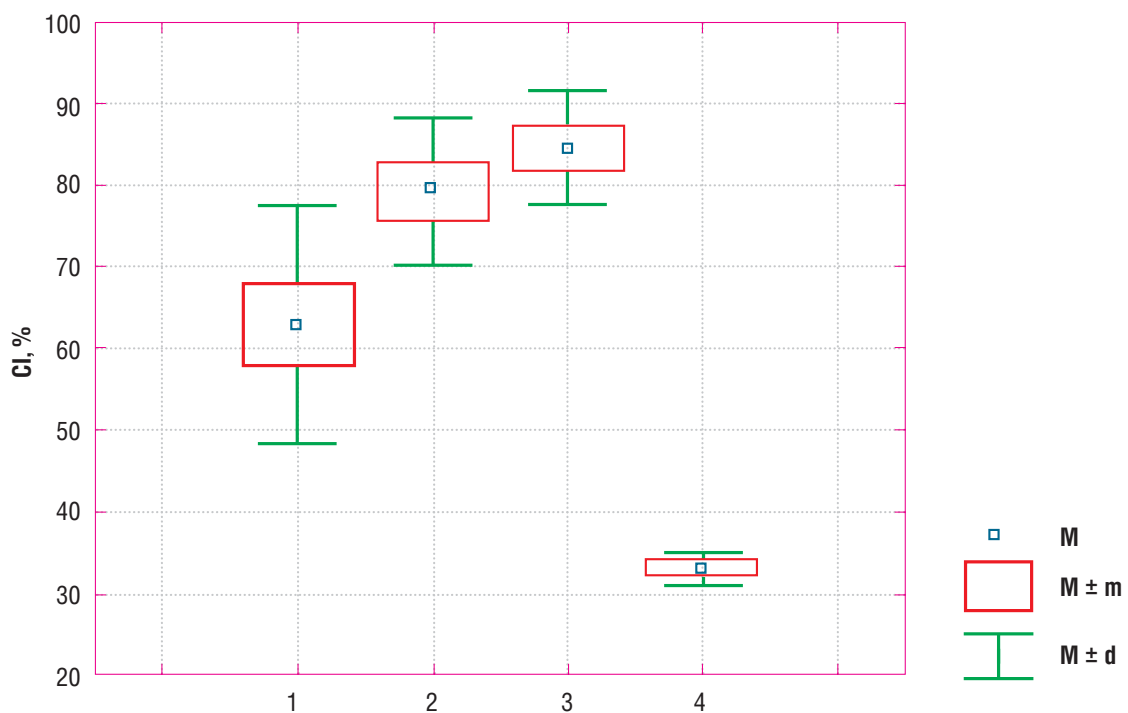

Figure 3. Cytotoxic activity of spleen mononuclear cells of animal from the research groups relatively to glioma 101.8 cells in vitro (MTT test, cytotoxic index,\%):

1) induction of glioma was carried out with native 101.8-glioma cells $(n=15)$;

2) induction of glioma was carried out with tumor cells modified with NCS at a concentration of $0.02 \mathrm{mg} / \mathrm{ml}(\mathrm{n}=15)$;

3) induction of glioma was carried out with tumor cells modified with NCS at a concentration $0.1 \mathrm{mg} / \mathrm{ml}(n=15)$;

4) intact rats (control, $n=15$ ).

\section{CONCLUSIONS}

1. 1. Modification of 101.8-glioma cells suspension via incubation with rat neurogenic cells supernatant (concentrations of $0.02 \mathrm{and} 0.1 \mathrm{mg} / \mathrm{ml}$ ) reduced tumor inducing ability of tumor cells delaying a debut of clinical manifestations of tumor and increasing the life expectancy of the experimental animals.

2. 2.Under conditions of the induction of glioma tumor cells, previously modified with NCS, there increased the cytotoxic activity of immunocompetent cells in tumor-bearing animals in vitro tests with glioma 101.8 allogeneic cells. 


\section{REFERENCES}

1. Achanta P, Sedora Roman NI, Quiñones-Hinojosa A. Gliomagenesis and the use of neural stem cells in brain tumor treatment. Anticancer Agents Med. Chem. 2010; 10(2):121-130.

2. Kim SU. Neural stem cell-based gene therapy for brain tumors. Stem Cell Rev. 2011; 7(1):130-140.

3. Ahmed AU, Ulasov IV, Mercer RW, et al. Maintaining and loading neural stem cells for delivery of oncolytic adenovirus to brain tumors. Methods Mol. Biol. 2012; 797:97-109.

4. Khosh N, Brown CE, Aboody KS, et al. Contact and encirclement of glioma cells in vitro is an intrinsic behavior of a clonal human neural stem cell line. PLOS ONE. 2012; 7(12): e51859.-Available: http://www.jourlib.org/paper/3003453

5. Aboody KS, Najbauer J, Metz MZ, et al. Neural Stem Cell-Mediated Enzyme/Prodrug Therapy for Glioma: Preclinical Studies. Sci. Transl. Med. 2013; 5(184):184-189.

6. Bovenberg MS. Advances in stem cell therapy against gliomas. Trends Mol. Med. 2013; 19(5):281-291.

7. Morshed RA, Gutova M, Juliano J, et al. Analysis of glioblastoma tumor coverage by oncolytic virus-loaded neural stem cells using MRI-based tracking and histological reconstruction. Cancer Gene Therapy. 2015; 22:55-61.

8. Shah Kh. Stem cell therapeutics for cancer. Wiley Blackwell, 2013. 304 p.

9. Hamerlik P. Cancer stem cells and glioblastoma In: Glioma cell biology. Sedo A, Mentlein R. (ed.). Wien: Springer-Verlag. $2014: 3-22$.

10. Nakada M, .Kita D, Furuta $T$, et al. Signalling cascades driving the malignant phenotype of glioma cells. In: Glioma cell biology. Sedo A., Mentlein R. (ed.). Wien: Springer-Verlag. 2014:47-76.

11. Halansky AS, Kondakova LI, Avtsyn AP. Novye perevivaemye gliomy golovnogo mozga krys [New transplantable rat brain glioma]. Voprosy nejrohirurgii - Questions of Neurosurgery Вопросы нейрохирургии, 1995; 2:23-25.

12. Lyubich LD, Lisyanyy MI. Sposib doslidzhennja alocytotoksychnoi' aktyvnosti imunokompetentnyh klityn [The method of study of allocytotoxicity activity of immunocompetent cells]. Patent UA 75059, Ukrai'na. Opubl. 26.11.2012. Bjul. 22. - Patent UA 75059, Ukraine. Publ. 26.11.2012. Bull. 22.

13. Ghosh A, Bhattacharya $M$, Sarkar $P$, et al. T11 target structure exerts effector function by activating immune cells in CNS against glioma where cytokine modulation provide favorable microenvironment. Indian J. Exp. Biol. 2010; 48(9):879-888.

14. Huang H, Hara A, Homma T, et al. Altered expression of immune defense genes in pilocytic astrocytomas. J. Neuropathol. Exp. Neurol. 2005; 64(10):891-901.

15. Nano R, Capelli E, Facoetti A, et al. Immunobiological and experimental aspects of malignant astrocytoma. Anticancer Res. 2009; 29:2461-2466.

16. Mehling M, Simon P, Mittelbronn M, et al. WHO grade associated downregulation of MHC class I antigen-processing machinery components in human astrocytomas: does it reflect a potential immune escape mechanism? Acta Neuropathol. 2007; 114(2):111-119.

17. Kren L, Muckova K, Lzicarova E, et al. Production of immune-modulatory nonclassical molecules HLA-G and HLA-E by tumor infiltrating ameboid microglia/ macrophages in glioblastomas: a role in innate immunity? J. Neuroimmunol. 2010; 220(1-2):131-135.

18. Kren L, Slaby O, Muckova $K$, et al. Expression of immune-modulatory molecules HLA-G and HLA-E by tumor cells in glioblastomas: an unexpected prognostic significance. Neuropathology. 2011; 2:129-134.

19. Klassen HJ, Imfeld KL, Kirov II, et al. Expression of cytokines by multipotent neural progenitor cells. Cytokine. 2003; 22(3-4):101-106.

20. Liu J, Götherström C, Forsberg M, et al. Human neural stem/progenitor cells derived from embryonic stem cells and fetal nervous system present differences in immunogenicity and immunomodulatory potentials in vitro. Stem Cell Res. 2013; 10(3):325-337.

21. Chen HC, Ma HI, Sytwu HK, et al. Neural stem cells secrete factors that promote auditory cell proliferation via a leukemia inhibitory factor signaling pathway. J. Neurosci. Res. 2010; 88(15):3308-3318.

22. Lyubich LD. Ocinka vplyvu supernatantu progenitornyh nejroklityn shhura na ekspresiju antygeniv CD25 ta CD95 klitynamy gliom ljudyny [Assessing the impact of the supernatant progenitor neural cells rat on expression of CD25 and CD95 antigens of human gliomas]. Imunologija ta alergologija. Nauka i praktyka - Immunology and Allergology. Science and Practice, 2012; 2:31-36.

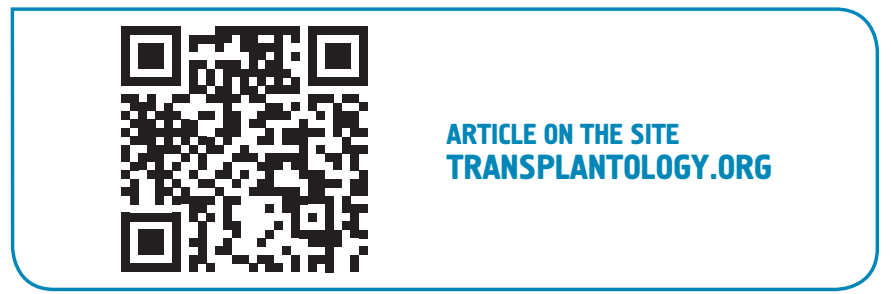

